\title{
The Effects of World War II Military Service: Evidence from Australia
}

\author{
Alex Cousley, Peter Siminski, and Simon Ville
}

\begin{abstract}
Outside of the United States, few studies have estimated the effects of World War II service. In Australia, general war-time conscription and minimal involvement in the Korean War led to large cohort differences in military service rates, which we use for identification. We find a small, temporary negative effect on employment and a substantial positive effect on post-school qualifications, but not at the university level. While service increased home ownership slightly, it greatly reduced outright home ownership, consistent with the incentives provided by veterans' housing benefits. We also find a positive effect on marriage, but only from 1971.
\end{abstract}

$\mathrm{W}$ orld War II (WWII) had a devastating effect globally, with at least 60 million individuals, mostly civilians, losing their lives. The events of WWII surpassed WWI in their "utter ruthlessness," due to advances in military technology, especially the aerial bombardment of major cities (Marwick 1974, p. 2). The focus of WWII research, in most countries, has therefore been to study the effects of war on broad populations rather than on servicemen (Akbulut-Yuksel 2014; Ichino and Winter-Ebmer 2004; Kesternich et al. 2014; Acemoglu, Hassan, and Robinson 2011; Harrison 1998).

There is, nevertheless, a substantial literature on WWII service effects in the United States, where civilians were not directly affected since North America was beyond the main battle zones for most of the war. Another driver of this body of literature is the prominence of the GI Bill, which was established as the key repatriation mechanism after WWII and

The Journal of Economic History, Vol. 77, No. 3 (September 2017). (C) The Economic History Association. All rights reserved. doi: 10.1017/S0022050717000717

Alex Cousley, University of Wollongong, School of Economics, Wollongong Wollongong New South Wales 2522, Australia. E-mail: acousley@uow.edu.au. Peter Siminski is Associate Professor, University of Wollongong, School of Accounting, Economics and Finance, Wollongong New South Wales 2522, Australia. E-mail: siminski@uow.edu.au. Simon Ville is Senior Professor, University of Wollongong, School of Humanities and Social Inquiry, Wollongong New South Wales 2522, Australia. E-mail: sville@uow.edu.au.

We are grateful to the editors (Paul Rhode and William Collins), two anonymous referees, Denzil Fiebig, Tim Hatton and Alfredo Paloyo, seminar participants at Deakin University, University of Melbourne, ANU, UTS, and at the 3rd Australasian Cliometrics Workshop for comments and discussions which improved the paper greatly. We thank the Department of Veterans' Affairs and Australian Bureau of Statistics for access and assistance with de-identified data. Siminski acknowledges grant support from the Australian Research Council (DE120101642). 
remains in place today. The GI Bill is seen as a major driver of educational and social change in twentieth-century America (Goldin and Katz 2009).

Some of this research has addressed potential selection bias through the use of quasi-experimental techniques. Joshua Angrist and Alan Krueger (1994) found that the relatively high earnings of WWII veterans are explained by selection rather than a causal impact of service. One of the strongest findings is that service increased college education considerably, most likely through the GI Bill (Bound and Turner 2002). ${ }^{1}$ Matthew Larsen et al. (2015) found that this increased college participation also led veterans to marry more educated wives. They also found no effect on marital status at 1970. Daniel Fetter (2013) found eligibility for veterans' housing benefits (especially through a mortgage guarantee) shifted home purchase earlier in the life course for many men. Kelly Bedard and Olivier Deschênes (2006) found that military service increased the rate of postservice mortality, especially from smoking-related causes. ${ }^{2}$

WWII was also particularly significant for Australia. It was the first time that Australia had faced the threat of invasion, requiring a full mobilisation of the economy (Beaumont 1996). As part of this, conscription on wartime service was introduced for the first time and almost a million Australians entered the armed service, with hundreds of thousands more in auxiliary and war industries (Lloyd and Rees 1994). This represented more than 40 percent of the adult male population (Australian Bureau of Statistics 1938, pp. 351, 376).

There are a number of similarities and differences between the two countries which provide context for comparisons of results. Like the United States, the war was largely fought beyond Australia's shores. Death rates were comparable, as was average length of service. ${ }^{3}$ Both countries provided generous benefits to veterans, including for education, housing and employment protection, as well as disability compensation.

\footnotetext{
${ }^{1}$ Stanley (2003) also finds similar results. Turner and Bound (2003) found that this education effect was not shared by black men in the South of the United States. Lemieux and Card (2001) find similar overall effects on education for Canada.

${ }^{2}$ Other (non-experimental) research has also been conducted, examining the association between service and health, mortality, earnings, crime, education, and marital status (Sutker and Allain 1996; Fontana and Rosenheck 1994; Keehn 1980; Teachman and Tedrow 2004; Sampson and Laub 1996; Pavalko and Elder 1990). Much of this work has explored the experience of different types of service, particularly those in combat roles and prisoners of war, often using data from surveys and interviews. It has addressed life course aspects such as whether older or younger servicemen were affected differently and the impact on different social and racial groups.

${ }^{3}$ In WWII 3.8 percent of Australian service personnel died (authors' calculations from World War Two Nominal Roll 2002) and 2.5 percent for the United States (Chambers 1999, p. 849). Average length of service was 41 months for Australia (authors' calculations from World War Two Nominal Roll 2002) and 33 months for the United States (Goralski 1981, p. 422).
} 
And in both countries these benefits have been proposed as a key driver of post-war human capital investment (Goldin and Katz 2009; Anderson and Eaton 1982). A key difference, however, is that university enrolment rates were much lower in Australia prior to WWII and indeed subsequently.

We know of no previous econometric work on the effects of WWII service for Australians and we address this void. ${ }^{4}$ Our approach is to exploit large cohort differences in military service rates. More than 90 percent of Australian men born in the early 1920s served in WWII. This percentage was close to zero for those born in the late 1920s. A key advantage of our study over U.S. work is that the number of Australians who served in the following decades was much smaller. In particular, veterans of the Korean War made up less than 3 percent of each one-year birth cohort. ${ }^{5}$ This avoids the problem faced by American research that cohorts just too young for WWII served in Korea in large numbers.

While data availability is a challenge for such a study, we draw on several sources. Military service participation rates by birth cohort (i.e., the first-stage data) are calculated from historical personnel records combined with estimated population counts by year of birth. The secondstage data are drawn from the five Australian Censuses of Population and Housing held between 1966 and 1986, which are the earliest Censuses from which the required data are available. The second-stage data show how various outcome variables differ between birth cohorts.

We consider effects on major life outcomes, specifically employment, education, housing, and marital status. ${ }^{6}$ We find a small negative effect on employment, but only in 1966 and not afterwards. We find little evidence that service (including through subsequent education benefits) increased university education, though it did increase the attainment rates of other post-school qualifications. This contrasts with the large effect found for the United States overall (Bound and Turner 2002; Stanley 2003), but is maybe unsurprising given that university education was rare and perhaps not a realistic option for many Australians of this era. In some respects,

\footnotetext{
${ }^{4}$ Previous research has consisted largely of oral and archival historical work. Garton (1996) and Damousi (2001) look at the effects of military service on the servicemen and their families, respectively. Garton (1996) suggests that military service had a negative impact on employment prospects, especially for those individuals who were captured prisoners of war.

${ }^{5}$ Between the WWII and Vietnam War eras, the largest contingent of Australians deployed to war was the approximately 18,000 men who served in Korea. This is about 1.8 percent of the number who served in the WWII era. Around 90 percent of Australia's Korea veterans were born between 1920 and 1935. But they make up less than 3 percent of the total number of men in any one-year birth cohort. (Source: Custom tabulations from the Nominal Roll of Australian Veterans of the Korean War, as at 11 March 2014.) Since we cannot identify which of the Korean veterans were also WWII veterans, we exclude Korean service from the analysis. The extent of resulting bias is likely trivial due to the low numbers of Korean veterans.

${ }^{6}$ We would like to also study effects on earnings and health, but we are not presently aware of any appropriate available data.
} 
this is analogous to the opportunities available to blacks in the South of the United States, for whom WWII service also did not enhance college education (Turner and Bound 2003).

We find a small positive effect on home ownership, likely due to veterans' housing benefits, and a much larger positive effect on having a mortgage, which is consistent with the incentives provided by veterans' housing benefits. We also find a positive effect on marriage, increasing in each Census from 1971, mirrored by negative effects on the probability of having never married.

\section{THE RECRUITMENT, SERVICE, AND COMPENSATION OF AUSTRALIAN SERVICEMEN}

\section{Recruitment and Service}

WWII was the first occasion Australians were conscripted into active wartime service. Compulsory military training existed during 19111929, but only volunteers were enlisted into active service in WWI, serving overseas as the Australian Imperial Force (Ville and Siminski 2011). On the outbreak of war in 1939, a second Australian Imperial Force of volunteers was raised to fight overseas. At the beginning of 1940, compulsory training was resumed. Unmarried men aged 21 were drafted for three months of training and then required to serve for three months (Dennis et al. 2008). The conscription coverage gradually broadened over the first two years of the war, eventually being fixed at 18-45 for single men and 18-35 for married men (Ville and Siminski 2011). Initially, conscripts were only required to serve in Australia, along with New Guinea and adjacent islands. In 1942, as the war in southeast Asia came closer to Australian shores, conscripts could be expected to serve in territories in the "South West Pacific Zone," which included Indonesia, the Philippines, and Japanese-held islands south of the equator. The Australian Army formed the majority of the defence force, with 728,000 enlisted (Robertson 1981, p. 64), compared with the Royal Australian Air Force (RAAF), with more than 200,000 recruits and the Royal Australian Navy with 37,000 recruits (Beaumont 2001, pp. 147, 181).

More than half of a million $(550,000)$ Australians went on active service overseas, about 1 in 12 of the population (Beaumont 1996, p. xx). Their experience of service was highly variable. Only a fraction of recruits were in front line activities that were likely to expose them directly to battle. Some Australians served in units alongside fellow countrymen, whereas others, especially in the RAAF, were part of a broader British Commonwealth force. While many Australians served in New Guinea and nearby Pacific 
islands, others found themselves in a variety of locations in Europe and the Middle East, which exposed them to quite different forms of engagement. The early campaigns in the Middle East were conducted on flat terrain, with aircraft and artillery bombardments regularly experienced (Gullett 1984). The Pacific saw the majority of combat in heavy jungle, involving close fighting in small groups where the front lines were often inaccessible to larger specialist weapons. Fighting in the Pacific also comprised short and intense engagement, compared with the drawn out battles of attrition in the Middle East (Long 1973). At least 27,000 Australians died as a result of combat, from wounds, or in prisoner of war camps. A further 23,000 were wounded or injured (Beaumont 1996, pp. xx, xxv; Long 1963, p. 634). Probably another 13,000 died in training or in non-combat situations while on service. ${ }^{7}$ We do not have data on how many were disabled.

\section{Repatriation}

Wartime service impacted upon an individual's workforce opportunities and capabilities. By being removed from the civilian workforce, servicemen missed out on a period of work experience or education and training, which could impact their lifetime earnings and employability. In addition, the physical or psychological damage caused by service could further affect employability. Offsetting these disadvantages, to some degree, were the training, discipline, camaraderie, and teamwork skills that formed part of the military experience (Johnston 1996; Elder and Clipp 1988; Costa and Kahn 2003, p. 520).

Repatriation policy in Australia, as elsewhere, recognised that the net effect of wartime service on future employment was probably negative. Compensation policies took several forms. The main compensatory payments of interest, dating back to WWI, were the disability payment (historically called the war pension) along with service pensions paid to veterans on the grounds of age, permanent incapacity to work, or total blindness (Department of Veterans' Affairs (DVA) 2003). Disability payments were based on the level of incapacity. Most countries, including Britain, used deciles working down from 100 percent. For Australia, any incapacity deemed below 10 percent was considered slight enough to warrant no compensation. Britain was slightly more stringent, with anything below 20 percent receiving no compensation (Garton 1996, p. 99). Since the Repatriation Act 1920, there is also a special rate of disability pension for those who are totally and permanently incapacitated (TPI), which pays above the normal pension (DVA 2003).

\footnotetext{
${ }^{7}$ Beaumont (1996, p. xx). Grey (1990, p. 187) believes the combat mortality figures are closer to 34,000 .
} 
Pension eligibility fell into two categories: those with or without operational service. Operational service included any service outside Australia, and domestic service which incurred danger from hostile forces (DVA 2003). Operational service had no effect on the range or level of compensation, but determined the standard of proof that would be applied. Disability pension claims by veterans with operational service have effectively been assessed under a "reverse-criminal" standard of proof since 1943 (DVA 2003, p. 85). Under this standard of proof, responsibility lay with the Department of Repatriation to prove that a veteran's injury or disability was not a result of military service. A civil standard of proof (balance of probabilities) was applied to claims made by veterans without operational service.

One of the new initiatives for the WWII veterans was the Commonwealth Rehabilitation Training Scheme (CRTS), which was available for all who had served at least six months and were honourably discharged. This was intended to equip and prepare returned servicemen and women with the skills and qualifications to help them re-enter the labor market at the end of the conflict (Garton 1996, pp. 81, 98-99). The CRTS provided them with the opportunity to undertake university education or enter technical education or apprenticeships by paying a living allowance and the cost of fees, tools of trade, and books (Lloyd and Rees 1994).

In addition to the CRTS and liberal pension offerings, servicemen returned to a period of post-war reconstruction, increased economic activity, and high levels of growth in employment and incomes (Garton 1996). Some servicemen may have been incentivized to take the disability pension rather than to work, given the liberal standard of proof. Conversely, the period of increased economic activity and job opportunities may have made servicemen less likely to take the pension.

Further assistance into the workforce was embodied in the employment preference policy. Dating back to WWI, the policy sought to ensure that no ex-servicemen were disadvantaged by employers in seeking to return to the workforce. Anecdotal evidence from disgruntled former servicemen suggests this policy was difficult to monitor and enforce. Even in the public service, where government could exercise a more direct influence, returning servicemen often had to work their way up the ladder in competition with younger employees (Garton 1996, pp. 89-91).

\section{Housing Benefits}

A severe shortage of housing among discharged servicemen after both world wars motivated a housing benefits policy. Employment 
disadvantages and absence while on service might impact a veteran's ability to become a home owner. Beginning in 1918, under the Defence Service Homes (DSH) Scheme, veterans who had been on active overseas service were able to access loans to purchase or build their home on terms preferential to the market including low interest rates, no deposit, extended payment terms, and rent-to-purchase provisions. Initially, the government had in mind building houses in blocks to sell to veterans. Within a few years this had failed due to the inexperience of the War Services Homes Commissioner and the urgency of housing demand. In its place, applicants could be funded to build their own home or to buy a new or existing one including refinancing mortgages. This was normally restricted to one loan for one house except when a veteran relocated for work reasons. Such measures continued during and after WWII: the maximum loan amounts were regularly increased and the scope of the policy was extended in 1941 to cover the air force, all nursing services, and spouses (Australian Housing Corporation 1976: part 1, attachments A-G). The United States had a similar scheme as part of the GI Bill (Ingold 1991).

Between 1944-1945 and 1975 there were around 426,000 applications for home loans from among 582,000 qualifying former servicemen, most of whom served in WWII. Of these, approximately 268,000 servicemen had received grants by 1975 , a take up rate of 46 percent among eligible veterans (Australian Housing Corporation 1976: part 2, attachments $\mathrm{H}-\mathrm{O}$ ). The Commonwealth-State Housing Agreement (CSHA) was also established in 1945 to address the general housing shortage. It focussed on rental support and allocated 45 percent of its budget to defence force veterans. The revised 1956 CSHA shifted focus to encourage home ownership through low interest rate loans or subsidised purchase prices. But the scheme was dwarfed by the DSH since only 3,402 homes were purchased by ex-servicemen by 1975 through the CSHA (Australian Housing Corporation 1976, p. 61).

\section{METHODS}

Our empirical approach exploits between-cohort variation in military participation rates. We wish to estimate the effects of military service and subsequent benefit eligibility $(S)$ on various outcome variables $(Y)$ for person $i$ in birth cohort $j$ in the following equation:

$$
Y_{i j}=\beta_{0}+\beta_{1} S_{i j}+f\left(A_{j}\right)+\varepsilon_{i j},
$$

where $\beta_{1}$ is the causal parameter of interest, $f\left(A_{j}\right)$ is some polynomial function of age in years, and $\varepsilon_{i j}$ includes all other individual determinants 
of $Y$. Due to the selection process applied to enlistees and potential selfselection, ordinary least squares (OLS) estimation would likely yield biased estimates of $\beta_{1}$, due to correlation between $S_{i j}$ and the error term, $\varepsilon_{i i^{\prime}}$ Even the inclusion of a rich set of control variables is unlikely to fully avoid such omitted variable bias, as some of the determinants of most outcome variables may be correlated with military service are unobserved (e.g., intelligence and health).

We avoid such omitted variable bias by using an instrumental variable (IV) strategy. The instrument we use is the overall military participation rate within each one-year birth cohort $\left(\bar{S}_{j}\right)$, which is plausibly exogenous. The first stage equation is therefore:

$$
S_{i j}=\pi_{0}+\pi_{1} \bar{S}_{j}+g\left(A_{j}\right)+\epsilon_{i j}
$$

where $g\left({ }^{*}\right)$ is the same order polynomial as $\left.f^{*}\right)$. As discussed by Guido Imbens and Wilbert van der Klaauw (1995), the predicted value from this equation $\left(\hat{S}_{i j}\right)$ is identical to $\bar{S}_{j}$, because none of the regressors in the equation vary within cohorts. As we discuss in the following section, we obtain population level data for $\bar{S}_{i}$. Therefore, the first stage regression estimates are not subject to sampling error, again following Imbens and van der Klaauw (1995).

The second stage equation is therefore:

$$
Y_{i j}=\beta_{0}+\beta_{1} \bar{S}_{j}+f\left(A_{j}\right)+e_{i j} .
$$

This equation can be estimated by OLS. However, $\bar{S}_{j}$ varies only between cohorts, and so it is appropriate to account for potential inter-cohort correlation of the error term. Since the number of birth cohorts is reasonably small in our case, cluster-robust standard errors may not be reliable (Angrist and Pischke 2008, p. 313). Since all regressors vary only between cohorts, we instead adopt a group-means approach (p. 313). In this approach, the data are collapsed to the cohort level:

$$
\bar{Y}_{j}=\beta_{0}+\beta_{1} \bar{S}_{j}+f\left(A_{j}\right)+e_{j} .
$$

Equation (4) is estimated by Generalized Least Squares with weights proportional to the number of individuals in each cohort so that the point-estimates are identical to OLS estimates of equation (3) and the standard errors appropriately account for clustering within each cohort. To account for the possibility of heteroscedasticity while considering the small samples we use, we show HC3 standard errors (Davidson and MacKinnon 1993). In almost all of our models, these standard errors are 
larger than the corresponding $\mathrm{HC} 2$, ordinary robust, or OLS standard errors. $^{8}$

Key practical considerations are the order of the polynomial functions of age, and the bandwidth of cohorts to include in the analysis. On one hand, smaller bandwidths and higher order polynomials are preferred because any remaining variation in $Y_{j}$ is more likely due to cohort differences in service. On the other hand, larger bandwidths and lower order polynomials usually yield smaller standard errors. In the main analysis, we use a quadratic specification and an estimation sample of 17 birth cohorts. While these are essentially arbitrary choices, we consider sensitivity of each estimate to cubic and linear specifications, as well as to alternate bandwidths ranging from 9 to 29 birth cohorts. The results of these extensive sensitivity tests are shown for the key outcome variables in the Online Appendix. For the linear specification, we show estimates for 9 and 13 cohort bandwidths on the basis that the linear function is unlikely to reliably control for secular age differences for any larger age range. For the quadratic function we show estimates for 9, 13, 17, and 21 cohort bandwidths for similar reasons. For the cubic function, we show estimates for 17, 21, 25, and 29 cohort bandwidths, omitting results for smaller bandwidths as those are very imprecise and generally uninformative.

\section{DATA AND DESCRIPTIVE STATISTICS}

To implement the empirical strategy outlined earlier, we only require cohort-level data on military participation rates and the outcome variables. Given the historical nature of this study, even such data are not trivial to obtain, and certain assumptions were required.

The study population is the set of males who lived in Australia at the time of WWII. A cohort is defined by financial year of birth (that is, from July to June). We use financial years of birth (rather than calendar years, or indeed month of birth) to match what is available in the second-stage data.

\section{First-Stage Data}

For the first-stage, we require military participation rates for males by financial year of birth. ${ }^{9}$ The numerators of these proportions are estimated

\footnotetext{
${ }^{8}$ Our approach is similar in principle to other work which exploits between-cohort differences in WWII service probability for identification, such as Angrist and Krueger (1994) and Bound and Turner (2002). The main difference is that we do not have access to a single data source with all required variables, and so we draw on separate sources of data for the first- and second-stages of the IV model, similarly to Imbens and van der Klaauw (1995). We elaborate on this in the following section.

${ }^{9}$ Veteran status was not recorded in any of the second-stage data sources that we use.
} 
using the World War Two Nominal Roll (World War Two Nominal Roll 2002). The denominators are taken from the 1933 and 1947 Australian Censuses. ${ }^{10}$

The Nominal Roll was created to honour those Australians who served in WWII. It includes data from service records held by the Department of Defence, as well as data from the Commonwealth War Graves Commission for those who died in service. It includes DOB, residency, start and end date of service, date of death, and prisoner of war status. The records are held by the National Archives of Australia.

These counts are subject to measurement error for three reasons. First, the Nominal Roll does not record gender. In personal correspondence, DVA advised that the Nominal Roll includes an estimated 60,000 women overall (or 5.88 percent of the total). Without further information on the age distribution of those women, we assume that this proportion is constant across cohorts, and we deflate the counts accordingly. Second, there are multiple records in the Nominal Roll for some individuals who had a break in service. We have been advised by the data custodians that the extent of such duplication has never been estimated, on the basis that many such duplicates likely contain minor changes in personal details, due either to recording inaccuracy or to enlistees' strategic reasons. Finally, 108,320 records (approximately 10 percent) are missing date of birth (DOB). Those records are excluded. It is difficult to gauge whether the upward bias due to duplicate records is of similar magnitude to the offsetting (10 percent) downward bias due to missing DOB. But the duplication of records would need to exceed 20 percent of the overall count for that count to be biased by more than 10 percent. A further limitation of the Nominal Roll is that it does not flag those who were deployed, and so we cannot attempt to separately identify the effects of deployed and non-deployed service.

The denominator of the participation rates (i.e., counts of men by year of birth) is sourced from published data from the 1933 and 1947 Censuses. The 1933 Census was the last Census prior to WWII and the 1947 Census was the first one after WWII. We regard both as very good proxies for the size of the WWII-era male population by year of birth because migration was low during this era (Phillips, Klapdor, and SimonDavies 2010; Hatton and Withers 2015, p. 352). ${ }^{11}$ When constructing the

\footnotetext{
${ }^{10}$ For parsimony we refer to financial years in shorthand herein. For example, 1926 refers to the 1925-1926 financial year.

${ }^{11}$ Given that the 1933 Census was taken six years before the outbreak of the war, we considered adjustments for population change using historical population estimates, which are available in five-year age brackets at 30 June of each year (Australian Bureau of Statistics, 2014). But the size of each relevant five-year birth cohort barely changed between 1933 and 1938 (usually by less than 1 percent), and so adjustments were deemed unnecessary.
} 


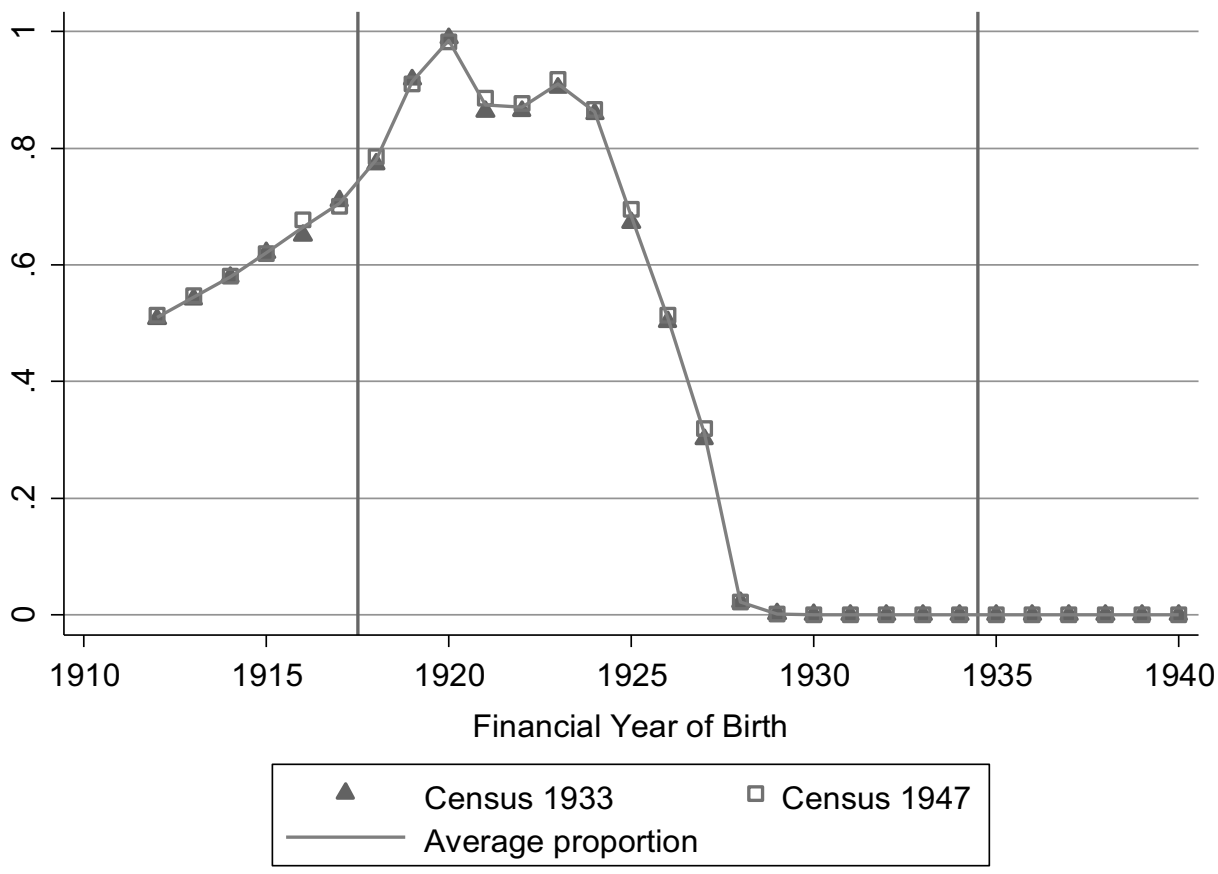

FIGURE 1

AUSTRALIAN MALE WWII MILITARY PARTICIPATION RATES BY YEAR OF BIRTH

Notes: The numerators for each birth year are calculated from the World War Two Nominal Roll after adjusting for gender composition. The denominators are taken from the 1933 and 1947 Censuses. For parsimony, 1912 refers to the 1911-1912 financial year birth-cohort, similarly for the other years. The main analysis uses those 17 birth cohorts between the vertical lines.

Source: Authors' calculations.

proportions using 1947 Census counts, we exclude men who died during WWII, since they are obviously excluded from the denominators as well.

Figure 1 shows the resulting estimated WWII participation rates for men born from 1911-1912 to 1939-1940, using the 1933 and 1947 Census counts, respectively, as well as the average of the two. ${ }^{12}$ Encouragingly, these proportions are not sensitive to the choice of 1933 or 1947 Census counts in the denominators. For the main analysis, we set the military service proportion for each birth year to the average of the two proportions calculated using population counts from the 1933 and 1947 Censuses, respectively.

Figure 1 also shows much variation in participation between birth cohorts, with a major drop from 86 percent for the 1924 cohort to just 2 percent in the 1928 cohort. This is due to the conflict coming to an end, and the subsequent reduced need for Australian manpower.

${ }^{12}$ The proportions estimated using 1933 denominators are assumed to be zero for cohorts born after the 1933 Census date. These males were aged 12 years or less when WWII ended. 
In our main analysis, the first-stage data consist of 17 observations, one for each year of birth between 1917-1918 and 1933-1934. These birth cohorts include approximately 1.02 million Australian men at the end of WWII. ${ }^{13}$ This data window was chosen to be centred around 1925-1926, which is the midpoint of the dramatic decline in service participation rates. We conduct extensive sensitivity tests to the bandwidth of this data window.

The upper panel of Table 1 shows descriptive statistics from the first stage database for the main estimation sample. Across the 17 birth cohorts, 46.7 percent of men served in the WWII era. Among those who did serve, 3.6 percent died in service, 2.1 percent were captured as prisoners of war, and the average length of service was 3.25 years.

\section{Second-Stage Data}

The data used in the second-stage regressions are from the five Australian Censuses of Population and Housing held between 1966 and 1986. Using the Australian Bureau of Statistics' customised data service, we obtained a set of tables derived from the full database from each Census, for which 100 percent of the Australian population was in scope. This service is not available for earlier Censuses. Specifically, these were two-way frequency tabulations for a range of outcome variables including labor market status, marital status, housing outcomes, and educational attainment, each by single year of age from each Census.

We used the customised service because these data are not available in published form, nor as microdata. Published two-way frequency tabulations from Census data are generally presented in five- or ten-year age bands, which is not sufficient for our analysis. Microdata sample files are available to researchers to access directly for Censuses held from 1981 onwards, but we preferred to instead draw on the custom tabulations from the full population.

Men who reported arriving in Australia after WWII were excluded from the tabulations. The number of remaining respondent males born between 1917-1918 and 1933-1934 was 958,307 in the 1966 data, declining in each subsequent Census to 808,532 for 1986 due presumably to mortality and emigration. This implies sample attrition rates of between 6 percent (at 1966) and 21 percent (at 1986). Such attrition may be related to military service, though it is not clear how much bias this

\footnotetext{
${ }^{13}$ The population for each birth year up to 1933 was set to the average of the counts from the 1933 and 1947 Censuses. The 1947 Census was used for younger birth cohorts (who were not yet born at the time of the 1933 Census).
} 
TABLE 1

DESCRIPTIVE STATISTICS

\begin{tabular}{|c|c|c|c|c|c|}
\hline Variable & & & Mean & & \\
\hline & t-Stage Da & & & & \\
\hline Military service & & & 0.467 & & \\
\hline Proportion of servicemen died & & & 0.036 & & \\
\hline Proportion of servicemen prisoners of war & & & 0.021 & & \\
\hline Years of service among servicemen & & & 3.25 & & \\
\hline Number of men & & & $1,021,600$ & & \\
\hline Number of birth cohorts & & & 17 & & \\
\hline $\operatorname{Sec}$ & nd-Stage D & & & & \\
\hline & 1966 & 1971 & 1976 & 1981 & 1986 \\
\hline Employed & 0.960 & 0.931 & 0.898 & & \\
\hline Not in labor force & 0.031 & 0.060 & 0.079 & & \\
\hline Unemployed & 0.009 & 0.008 & 0.023 & & \\
\hline Has any post-school qualification & & 0.340 & 0.445 & 0.390 & 0.441 \\
\hline Has university qualification & 0.029 & 0.032 & 0.035 & 0.038 & 0.040 \\
\hline Home owner & 0.707 & 0.711 & 0.721 & 0.746 & 0.768 \\
\hline Home owner without a mortgage & & & 0.342 & 0.447 & 0.587 \\
\hline Home owner with a mortgage & & & 0.376 & 0.277 & 0.181 \\
\hline Renter & 0.213 & 0.190 & 0.149 & 0.129 & 0.122 \\
\hline Number of (bed)rooms in dwelling* & 5.614 & 5.443 & 2.928 & 2.932 & 2.876 \\
\hline Married & 0.834 & 0.836 & 0.826 & 0.805 & 0.788 \\
\hline Permanently separated or divorced & 0.039 & 0.049 & 0.062 & 0.078 & 0.084 \\
\hline Widower & 0.008 & 0.014 & 0.019 & 0.029 & 0.042 \\
\hline Never married & 0.119 & 0.101 & 0.092 & 0.088 & 0.085 \\
\hline Number of men & 958,307 & 944,988 & 881,588 & 855,985 & 808,532 \\
\hline Number of birth cohorts & 17 & 17 & 17 & 17 & 17 \\
\hline
\end{tabular}

* The Census collected data on number of rooms in the dwelling in 1966 and 1971, and the number of bedrooms in subsequent years.

Source: The first-stage database was created by the authors drawing on data from the World War Two Nominal Roll and the 1933 and 1947 Australian Censuses. The second-stage data are sourced from the five Australian Censuses of Population and Housing held between 1966 and 1986. In each case, the sample is restricted to men born between July 1917 and June 1934. PostWWII migrants are excluded from the second-stage data.

would contribute to our estimates. We are not aware of any Australian studies that have estimated the link between WWII service and postservice mortality.

The lower panel of Table 1 shows descriptive statistics for each secondstage database, limited to the estimation sample in our main analysis. It shows that 96 percent of men in these cohorts were employed in 1966, when they were 32-48 years old. The corresponding proportions were 93 percent in 1971 and 90 percent in 1976. The proportion unemployed was below 1 percent in 1966 and 1971, and 2.3 percent in 1976, while the 
remainder were not in the labor force. We do not consider labor market outcomes using 1981 or 1986 Census data, because many of the relevant birth cohorts were aged 60 or over by then. There is a considerable discontinuity in employment rates at age 60 in each Census year, because many people retire at this age. In this context, our strategy of controlling for secular differences between cohorts using polynomial functions of age would not be reliable if the data window were to span those discontinuities.

Table 1 also shows the very low level of university qualifications by this cohort, between 2.9 percent in 1966 and 4.0 percent in 1986. A much higher proportion of men had some form of post-school qualification. In each census, a majority of such qualified men had obtained a trade qualification. ${ }^{14}$

The proportion of men who were home owners was 70.7 percent in 1966, increasing further with each census up to 76.8 percent in 1986. From 1976 onwards, home-owners with and without a mortgage were separately identifiable. In 1976, slightly more than half of them had a mortgage. By 1986 it was less than a quarter. The proportion living in rental accommodation declined steadily from 21.3 percent in 1966 to 12.2 percent in 1986. In 1966 and 1971, data were collected on the number of rooms in the dwelling. Among men in these cohorts, the average number of reported rooms was 5.6 in 1966 and 5.4 in 1971. Subsequent Censuses instead asked about the number of bedrooms, for which the average response was 2.9 in each year for these cohorts.

Table 1 also shows the progression of marital status between 1966 and 1986. The proportion married was high in all years, but declined from a peak of 83.6 percent in 1971 to 78.8 percent in 1986 . The proportion never married also declined from 11.9 percent in 1966 to 8.5 percent in 1986. During this same period, the proportion permanently separated or divorced more than doubled from 3.9 percent to 8.4 percent, and the proportion who were widowers increased by a similar share from 0.8 percent to 4.2 percent.

Our empirical approach relies on the assumption that smooth functions of age adequately control for all non-service factors that vary between cohorts. We scrutinise this assumption for key outcome variables in Figure 2 , using 1976 Census data. The upper-left panel shows the proportion of men classified as employed by birth year. This variation is indeed very

${ }^{14}$ In the 1971 Census, the relevant question was "Since leaving school has this person obtained a trade or other qualification?" Subsequent censuses used similar wording. However, the non-monotonic change over time suggests that there may be some discrepancies between censuses in how responses to this question were coded by the Australian Bureau of Statistics. The corresponding data item in 1966 only includes "university" and "other tertiary" qualifications and is excluded from the analysis. 

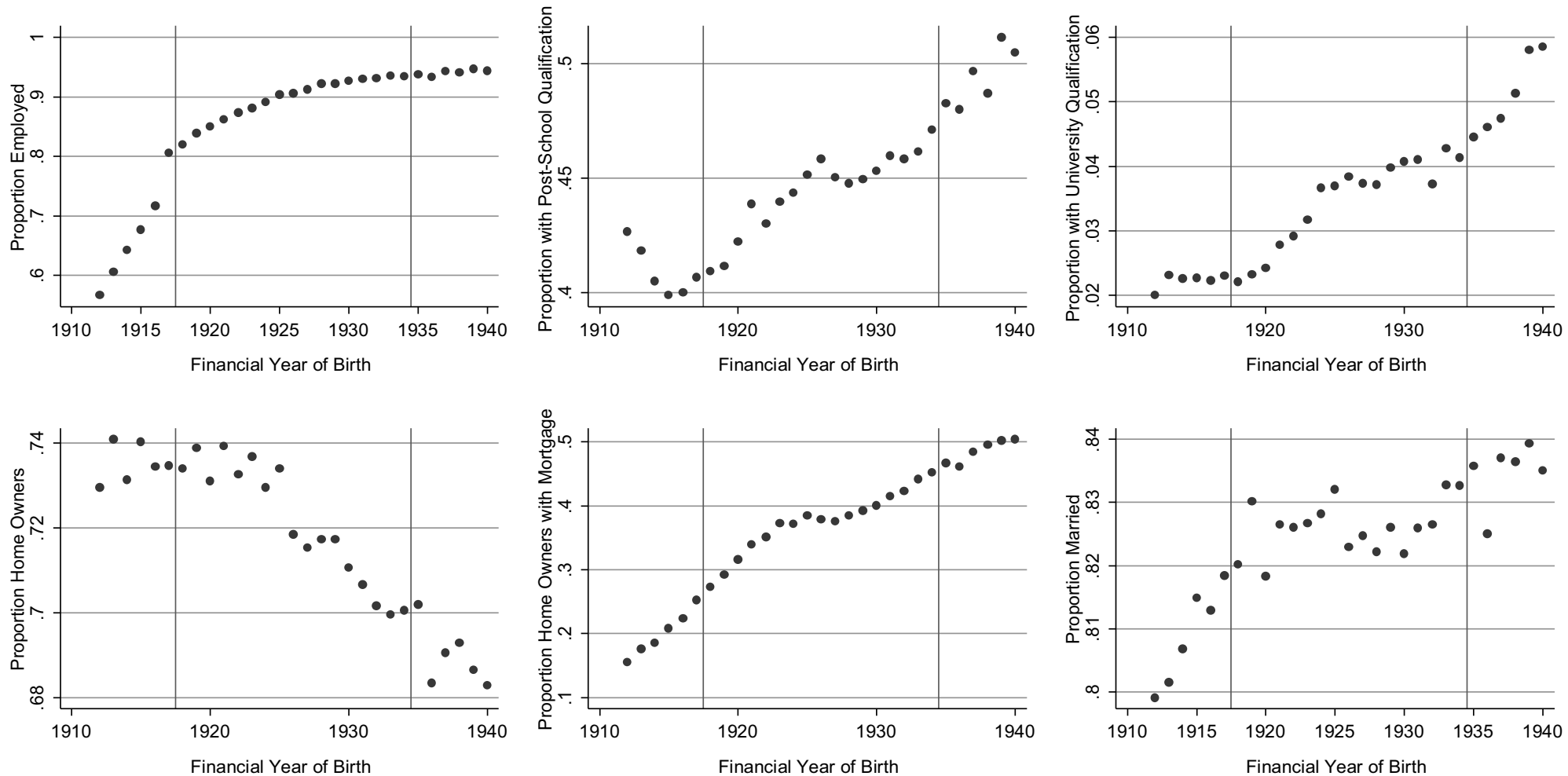

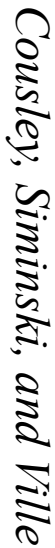

FIGURE 2

KEY OUTCOME VARIABLES AT 1976, FOR MALES BY FINANCIAL YEAR OF BIRTH

Source: Authors' calculations from 1976 Census of Population and Housing. Males who arrived in Australia after WWII are excluded. The main analysis uses those 17 birth cohorts between the vertical lines. 
smooth, at least from the 1917 birth cohort onwards. Indeed, a quadratic function of age explains 99.1 percent of the variation in employment rates between cohorts, after excluding pre-1917 birth cohorts. The discontinuity at age 60 (i.e., between the 1916 and 1917 cohorts) is not surprising, because eligibility for some pensions and annuities commences at age 60. There are similar discontinuities in other Census years. We therefore exclude cohorts older than 60 from any version of the analysis of labor market outcomes. The rationale is that any smooth function of age is not an adequate control for non-service differences between cohorts.

The upper-middle panel of Figure 2 shows a similar scatterplot for attainment of post-school qualification, albeit with a different scale on the vertical axis. This proportion increases steadily between the 1916 and 1926 birth cohorts, falls between the 1926 and 1928 cohorts, then continues its upward trajectory. The corresponding plot for university qualifications follows a similar pattern (upper-right panel), albeit with a less pronounced drop between the 1926 and 1928 cohorts, and with a much smaller proportion throughout.

The lower-left panel of Figure 2 shows the scatterplot for home ownership. Here, there is little variation between cohorts up to the 1925 birth cohort, before dropping steadily for younger birth cohorts. The lowermiddle panel shows the unconditional proportion of men that own their home, but have a mortgage. There is much variation in this series across cohorts, varying from around 16 percent for the oldest cohort to 50 percent for the youngest cohort, reflecting life-course differences in mortgage repayment. This variation appears very smooth, but not monotonic. In particular, the series briefly turns downward at the same cohorts where military service rates also fall (Figure 1). A similar pattern is evident in the corresponding plots for the other Census years where this variable is available.

The lower-right panel of Figure 2 shows a corresponding scatterplot, for the proportion of men who were married, which is high for every birth cohort. It is characterised by an upward trend. The proportions for the early-1920s birth cohorts appear somewhat higher than the overall trend.

\section{RESULTS AND DISCUSSION}

\section{Labor Market Outcomes}

Table 2 shows the estimated effects of military service on labor market outcomes from a series of IV regressions. Since the values of the parameters in the first-stage equation are known without sampling error, there 
TABLE 2

INSTRUMENTAL VARIABLE REGRESSION RESULTSLABOR MARKET OUTCOMES

\begin{tabular}{|c|c|c|c|}
\hline Census Year & $\begin{array}{c}(1) \\
1966\end{array}$ & $\begin{array}{c}(2) \\
1971\end{array}$ & $\begin{array}{c}(3) \\
1976\end{array}$ \\
\hline & \multicolumn{3}{|c|}{ A: Employed } \\
\hline Service & $\begin{array}{c}-0.0042 * * \\
(0.0015)\end{array}$ & $\begin{array}{l}-0.0015 \\
(0.0038)\end{array}$ & $\begin{array}{c}0.0013 \\
(0.0054)\end{array}$ \\
\hline \multirow[t]{2}{*}{$N$} & 17 & 17 & 17 \\
\hline & \multicolumn{3}{|c|}{ B: NILF } \\
\hline Service & $\begin{array}{c}0.0033 * * \\
(0.0014)\end{array}$ & $\begin{array}{c}0.0011 \\
(0.0039)\end{array}$ & $\begin{array}{l}-0.0019 \\
(0.0054)\end{array}$ \\
\hline \multirow[t]{2}{*}{$N$} & 17 & 17 & 17 \\
\hline & \multicolumn{3}{|c|}{ C: Unemployed } \\
\hline Service & $\begin{array}{c}0.0010 \\
(0.0007)\end{array}$ & $\begin{array}{c}0.0003 \\
(0.0006)\end{array}$ & $\begin{array}{c}0.0006 \\
(0.0018)\end{array}$ \\
\hline$N$ & 17 & 17 & 17 \\
\hline
\end{tabular}

Notes: This table shows estimated effects of WWII service on various outcomes, exploiting between-cohort variation in the probability of service through an IV model. The estimation sample consists of the 17 financial-year birth cohorts spanning July 1917 to June 1934. Each regression includes a quadratic function of age. Robust (HC3) standard errors are shown in parentheses. The data sources are described in the notes to Table 1 .

${ }^{*} p<0.10,{ }^{* *} p<0.05,{ }^{* * *} p<0.01$

Source: Authors' calculations.

is no first-stage regression output, following Imbens and van der Klaauw (1995), as discussed earlier. Each column shows results for a different Census year. ${ }^{15}$ Each estimate is derived from models which draw on the 17 birth cohorts centred around 1926 (i.e., 1918-1934), controlling for a quadratic trend in age. The Online Appendix shows extensive sensitivity tests to both the order of the age polynomial and the bandwidth. Unless otherwise specified, the results are not sensitive to these variations in specification.

The proportion of men employed is the dependent variable in Panel A. The estimates for each year are small and quite precise, despite the small number of observations in each regression. There is evidence of a small negative effect on employment in 1966 ( -0.4 percentage points),

${ }^{15}$ In each Census year, there is a clear discontinuity in employment at age 60 (and a larger discontinuity at age 65). For this reason, we do not estimate any models of labor market outcomes using estimation samples that include men aged 60 or over, as polynomials in age do not adequately control for secular differences between cohorts. This prevents the use of the 1981 and 1986 Censuses for studying labor market outcomes. 
but no evidence of an effect in 1971 or 1976 . These results are not generally sensitive to alternate specifications (Online Appendix Table A.1), although the cubic specification does suggest a possible negative effect on employment in 1971 as well.

Panels B and C show results for being not-in-labor-force (NILF) and unemployed, respectively. For 1966, there is a significant positive effect on NILF, which mostly offsets the negative employment effect. The estimated effect on unemployed is small and not statistically significant. There is no evidence that military service affected the chance of NILF or unemployment in 1971 or 1976, mirroring the absence of effects on employment.

This small and temporary effect suggests that most veterans were effectively reintegrated into the civilian labor market, perhaps assisted by government policy to prioritise veterans in public sector recruitment. Moreover, the negative experiences of wartime service should also be set against the positive aspects of training and camaraderie discussed earlier. The results lend only very limited and temporary support to the view that Australian servicemen fared worse in the labor market (Garton 1996). That said, employment is a crude measure of labor market outcomes. It would be informative to also study effects on earnings, but such data were not collected in the Census. Furthermore, we cannot rule out more substantial effects on employment in the period between WWII and 1966, for which we do not have data on employment or earnings.

\section{Educational Outcomes}

Results for educational outcomes are shown in Table 3, which has the same structure as Table 2, apart from including results for all five census years from 1966 to 1986 . Panel A shows that military service had a significant, but relatively modest, effect on post-school qualifications, increasing the rate of attainment by about 3 percentage points at 1971. This effect is equal to about 10 percent of the mean. The CRTS is presumably the mechanism for this effect.

However, Panel B shows that military service did not have a large effect, if any, on the rate of university qualifications, regardless of which Census year is analysed. This is in stark contrast to the experience of U.S. veterans, for whom the GI Bill greatly increased college education (Bound and Turner 2002).

This is perhaps unsurprising given that 90 percent of CRTS recipients had chosen vocational and technical, rather than university, education 
TABLE 3

INSTRUMENTAL VARIABLE REGRESSION RESULTSEDUCATIONAL QUALIFICATIONS

\begin{tabular}{|c|c|c|c|c|c|}
\hline Census Year & $\begin{array}{c}(1) \\
1966\end{array}$ & $\begin{array}{c}(2) \\
1971\end{array}$ & $\begin{array}{c}(3) \\
1976\end{array}$ & $\begin{array}{c}(4) \\
1981\end{array}$ & $\begin{array}{c}(5) \\
1986\end{array}$ \\
\hline & \multicolumn{5}{|c|}{ A: Any Post-School Qualification } \\
\hline Service & & $\begin{array}{c}0.0344 * * * \\
(0.0086)\end{array}$ & $\begin{array}{c}0.0212 * * \\
(0.0075)\end{array}$ & $\begin{array}{c}0.0244 * * \\
(0.0091)\end{array}$ & $\begin{array}{l}0.0165^{*} \\
(0.0084)\end{array}$ \\
\hline \multirow[t]{2}{*}{$N$} & & 17 & 17 & 17 & 17 \\
\hline & \multicolumn{5}{|c|}{ B: University Qualification } \\
\hline Service & $\begin{array}{c}0.0034 \\
(0.0025)\end{array}$ & $\begin{array}{c}0.0040 \\
(0.0028)\end{array}$ & $\begin{array}{c}0.0023 \\
(0.0038)\end{array}$ & $\begin{array}{c}0.0028 \\
(0.0032)\end{array}$ & $\begin{array}{c}0.0035^{*} \\
(0.0018)\end{array}$ \\
\hline$N$ & 17 & 17 & 17 & 17 & 17 \\
\hline
\end{tabular}

Notes: See Table 2 notes.

Source: Authors' calculations.

(Mackinnon and Proctor 2013, p. 439). Further corroborating evidence for this result is provided by the low prevalence of university qualifications for the 1919-1924 birth cohorts (of whom 90 percent had WWII service). Of these men, only 2.9 percent had obtained a university qualification by 1976. In comparison, 13.0 percent of U.S. men from the same birth cohorts were college graduates by $1970 .{ }^{16}$

This result conflicts with the conclusions reached by Australian scholars who relate the post-war expansion of university enrolments to the CRTS (Anderson and Eaton 1982, p. 10; Groenewegen 2009, pp. 57-59). From a very low base, university enrolments expanded considerably after WWII (Booth and Kee 2011, pp. 259-61). But there are other potential explanations for this: pent up demand, regular increases in government funding to the sector including scholarships, and changing popular attitudes and expectations towards tertiary education in the postwar era are all contenders. Our results motivate further research into the reasons for post-war university expansion in Australia.

\section{Housing Outcomes}

Results for housing outcomes are shown in Table 4, which follows the structure of the previous two tables. It suggests that the effects on housing were substantial. Panel A shows estimated effects on the probability of being a home owner. It shows evidence that military service increased

\footnotetext{
${ }^{16}$ Authors' calculations from two 1 percent sample files (combined) from the 1970 U.S. Census, using the IPUMS Online Data Analysis System.
} 
TABLE 4

INSTRUMENTAL VARIABLE REGRESSION RESULTSHOUSING OUTCOMES

\begin{tabular}{|c|c|c|c|c|c|}
\hline Census Year & $\begin{array}{c}(1) \\
1966\end{array}$ & $\begin{array}{c}(2) \\
1971\end{array}$ & $\begin{array}{c}(3) \\
1976\end{array}$ & $\begin{array}{c}(4) \\
1981\end{array}$ & $\begin{array}{c}(5) \\
1986\end{array}$ \\
\hline & \multicolumn{5}{|c|}{ A: Home Owner } \\
\hline Service & $\begin{array}{c}0.0179 * * * \\
(0.0046)\end{array}$ & $\begin{array}{c}0.0087 \\
(0.0050)\end{array}$ & $\begin{array}{c}0.0097 \\
(0.0064)\end{array}$ & $\begin{array}{c}0.0106^{* *} \\
(0.0045)\end{array}$ & $\begin{array}{l}0.0092 * \\
(0.0045)\end{array}$ \\
\hline \multirow[t]{2}{*}{$N$} & 17 & 17 & 17 & 17 & 17 \\
\hline & \multicolumn{5}{|c|}{ B: Home Owner without a Mortgage } \\
\hline Service & & & $\begin{array}{c}-0.0574 * * * \\
(0.0081)\end{array}$ & $\begin{array}{c}-0.0727 * * * \\
(0.0139)\end{array}$ & $\begin{array}{c}-0.0655^{* * *} \\
(0.0105)\end{array}$ \\
\hline \multirow[t]{2}{*}{$N$} & & & 17 & 17 & 17 \\
\hline & \multicolumn{5}{|c|}{ C: Home Owner with a Mortgage } \\
\hline Service & & & $\begin{array}{c}0.0676^{* * * *} \\
(0.0104)\end{array}$ & $\begin{array}{c}0.0830 * * * \\
(0.0168)\end{array}$ & $\begin{array}{c}0.0747 * * * \\
(0.0127)\end{array}$ \\
\hline \multirow[t]{2}{*}{$N$} & & & 17 & 17 & 17 \\
\hline & \multicolumn{5}{|c|}{ D: Renter } \\
\hline Service & $\begin{array}{c}-0.0166^{* * *} \\
(0.0040)\end{array}$ & $\begin{array}{l}-0.0029 \\
(0.0038)\end{array}$ & $\begin{array}{l}-0.0042 \\
(0.0053)\end{array}$ & $\begin{array}{l}-0.0045 \\
(0.0027)\end{array}$ & $\begin{array}{c}-0.0118^{* *} \\
(0.0044)\end{array}$ \\
\hline \multirow[t]{2}{*}{$N$} & 17 & 17 & 17 & 17 & 17 \\
\hline & \multicolumn{5}{|c|}{ E: Number of (Bed)rooms in Dwelling } \\
\hline Service & $\begin{array}{c}0.0174 \\
(0.0136)\end{array}$ & $\begin{array}{l}-0.0270 \\
(0.0304)\end{array}$ & $\begin{array}{l}-0.0280 \\
(0.0166)\end{array}$ & $\begin{array}{c}-0.0356^{* * *} \\
(0.0085)\end{array}$ & $\begin{array}{l}-0.0129 \\
(0.0085)\end{array}$ \\
\hline$N$ & 17 & 17 & 17 & 17 & 17 \\
\hline
\end{tabular}

Notes: See Table 2 notes.

Source: Authors' calculations.

the probability of home ownership in 1966 substantially (1.8 percentage points). For all later years, the point estimates are around 1 percentage point in each year, although they are not always statistically significant and somewhat sensitive to alternate specifications (Table A.4). Overall, these results suggest that veterans housing benefits did increase the probability of home ownership. The larger estimates for 1966 also suggest that veterans' benefits may have induced some veterans to purchase homes earlier than they would otherwise have done, consistent with Fetter's (2013) findings for the United States. ${ }^{17}$

The terms of the DSH Scheme were more favourable than those available from commercial borrowers. Repayment periods of between 32 and 45 years were significantly longer than for commercial loans of around

${ }^{17}$ Our estimated effect on homeownership at 1966 is much smaller than Fetter's estimate for the United States at 1960. Fetter found no evidence of an effect in 1970. 
20 to 30 years. In addition, veterans could effectively borrow 100 percent of the home value - 90 percent from the DSH with permission to obtain the remaining 10 percent from another borrower, compared with 70 to 90 percent normally offered by other lenders (Hill 1974, pp. 334-50; Australian Housing Corporation 1976, p. 35). The combination of longer terms and higher loan percentage made it easier for veterans to enter the housing market.

From 1976 onwards, the Census separately identifies home owners with and without mortgages. Panels $\mathrm{B}$ and $\mathrm{C}$ show results from models that use these as outcome variables. They show that military service had a large negative effect (around 6 or 7 percentage points in each year where we have data) on the probability of being an outright home owner without a mortgage, mirrored by a large positive effect on having a mortgage (around 7 or 8 percentage points). This suggests that the DSH greatly reduced the probability of paying off mortgages. The most likely reason for this is that DSH loans became cheap credit when commercial rates, already above DSH rates since WWII, rose and diverged sharply from the DSH rates from the early 1970s (Figure 3). The role of the DSH in influencing Australian home ownership patterns warrants further investigation.

Panel D shows results for the probability of living in a rented dwelling. It shows small negative effects of service, which are statistically significant in 1966 and 1986. These effects are consistent with the positive effects on home ownership in Column $1 .^{18}$

Panel E of Table 4 shows results for number of (bed)rooms in the residence. ${ }^{19}$ The number of rooms is a proxy for housing quality. The results suggest that service did not have a large effect on housing quality. If it did have an effect, it seems to have been negative. The point estimates are negative in each year since 1971 . However, only for 1981 is it statistically significant at the 5 percent level. The estimate is also largest in 1981 , suggesting a reduction in the number of bedrooms by 0.036 .

\section{Marital Outcomes}

Table 5 shows estimated effects on marital outcomes. The results suggest that effects on marital outcomes are small, but also that they changed over time. The results in Column 1 show little evidence that

\footnotetext{
${ }^{18}$ The discrepancies between the offsetting effects on home ownership and renting are due to some residual housing tenure categories in each Census, for which we do not show results.

${ }_{19}$ As discussed in Section 4, the number of rooms was recorded in 1966 and 1971, and the number of bedrooms was instead reported in subsequent Censuses.
} 


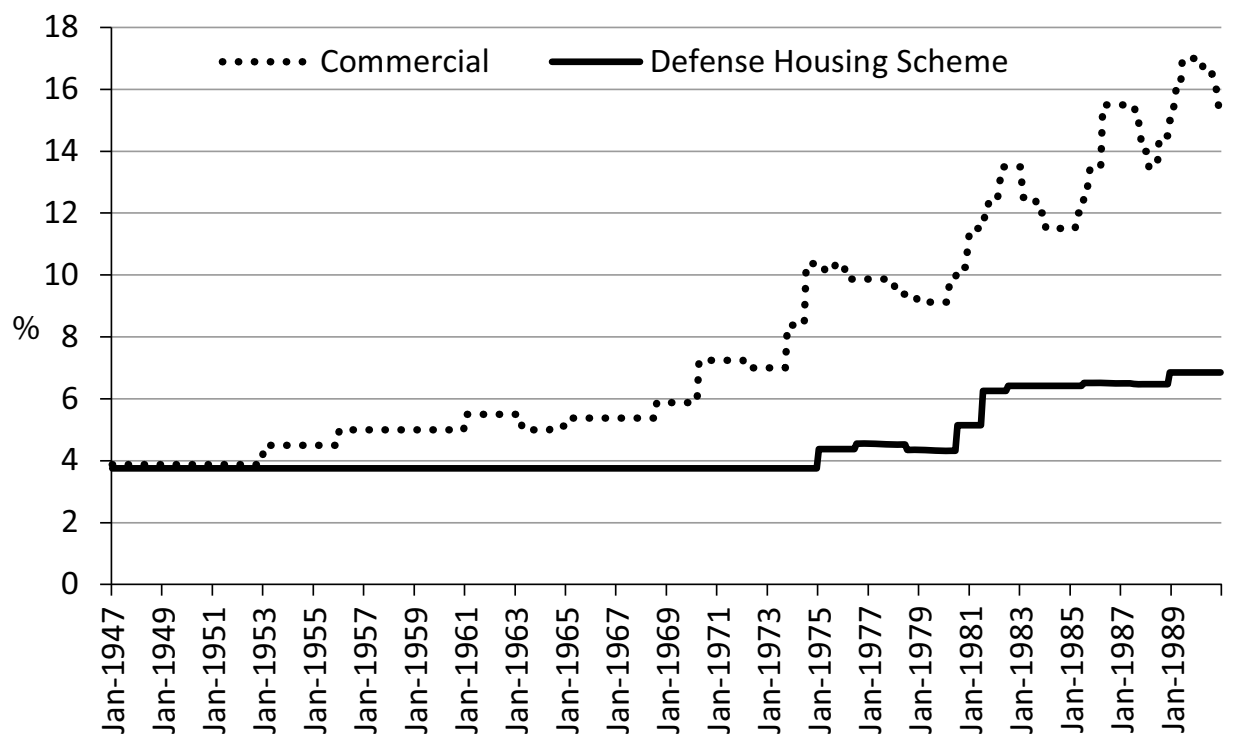

FIGURE 3

MORTGAGE INTEREST RATES BY SCHEME AND MONTH

\section{Sources:}

Commercial interest rates

1947-1950: Makeham-Kirchner, A (2007) 'Home loan interest rates and repayments', Parliament of Australia, http://www.aph.gov.au/About_Parliament/Parliamentary_Departments/ Parliamentary_Library/pubs/BN/0708/HomeLoanInterestRates

1950-1959: Reserve Bank of Australia, Australian Economic Statistics 1949-1950 to 1996-1997, Occasional Paper No. 8, No. 3.21b, RBA, Sydney.

1959-1990: Reserve Bank of Australia 2013, Indicator Lending Rates, Cat. No. F5, RBA, Sydney.

\section{Defence Service Homes Scheme}

Although an interest rate of 5 percent per annum was specified in the first War Service Homes Act 1918, the actual rate charged was 3.75 percent from 1946 until the Defence Service Homes Act 1974, when a stepped rate was adopted: 3.75 percent up to $\$ 12,000$, thereafter 7.25 percent. From March 1980 to November 1988 balances over \$15,000, were charged 10 percent. In our Figure, the DSH interest rate between 1974 and 1988 is based on an "average blended rate" calculated by determining the average loan per house. In Defence Service Homes Amendment Act 1988, an interest rate of 6.85 percent was adopted. Malcolm R. Hill, "Housing Finance Institutions" in The Australian Capital Market, edited by Ronald R. Hirst and Robert H. Wallace, p. 349. Melbourne, Australia: Cheshire, 1974. Australian Bureau of Statistics, Year Book Australia, each year 19741988, Cat. No. 1301.0, ABS, Canberra.

military service affected marital outcomes in 1966. However, the effect on the probability of being married is positive and highly significant in each of the other Census years (Panel A). While the estimate is rather small in each year, it increases over time, reaching 1.6 percentage points in 1986.

Panels B and C show no significant effects on the probability of being "divorced or permanently separated," or of being a widower at any of 
TABLE 5

INSTRUMENTAL VARIABLE REGRESSION RESULTSMARITAL STATUS

\begin{tabular}{|c|c|c|c|c|c|}
\hline Census Year & $\begin{array}{c}(1) \\
1966\end{array}$ & $\begin{array}{c}(2) \\
1971\end{array}$ & $\begin{array}{c}(3) \\
1976\end{array}$ & $\begin{array}{c}(4) \\
1981\end{array}$ & $\begin{array}{c}(5) \\
1986\end{array}$ \\
\hline & \multicolumn{5}{|c|}{ A: Married } \\
\hline Service & $\begin{array}{c}0.0019 \\
(0.0049)\end{array}$ & $\begin{array}{l}0.0094 * \\
(0.0051)\end{array}$ & $\begin{array}{c}0.0134 * * * \\
(0.0041)\end{array}$ & $\begin{array}{c}0.0143 * * \\
(0.0050)\end{array}$ & $\begin{array}{c}0.0157 * * * \\
(0.0051)\end{array}$ \\
\hline \multirow[t]{2}{*}{$N$} & 17 & 17 & 17 & 17 & 17 \\
\hline & \multicolumn{5}{|c|}{ B: Divorced or Permanently Separated } \\
\hline Service & $\begin{array}{c}0.0035 \\
(0.0024)\end{array}$ & $\begin{array}{l}-0.0003 \\
(0.0017)\end{array}$ & $\begin{array}{l}-0.0015 \\
(0.0022)\end{array}$ & $\begin{array}{c}-0.0020 \\
(0.0019)\end{array}$ & $\begin{array}{l}-0.0039 \\
(0.0024)\end{array}$ \\
\hline \multirow[t]{2}{*}{$N$} & 17 & 17 & 17 & 17 & 17 \\
\hline & \multicolumn{5}{|c|}{ C: Widower } \\
\hline Service & $\begin{array}{c}0.0013 \\
(0.0009)\end{array}$ & $\begin{array}{l}-0.0004 \\
(0.0008)\end{array}$ & $\begin{array}{c}0.0015 \\
(0.0022)\end{array}$ & $\begin{array}{l}-0.0012 \\
(0.0013)\end{array}$ & $\begin{array}{c}0.0005 \\
(0.0031)\end{array}$ \\
\hline \multirow[t]{2}{*}{$N$} & 17 & 17 & 17 & 17 & 17 \\
\hline & \multicolumn{5}{|c|}{ D: Never Married } \\
\hline Service & $\begin{array}{l}-0.0067 \\
(0.0049)\end{array}$ & $\begin{array}{l}-0.0087 \\
(0.0053)\end{array}$ & $\begin{array}{c}-0.0135 * * * \\
(0.0030)\end{array}$ & $\begin{array}{c}-0.0111^{* *} \\
(0.0044)\end{array}$ & $\begin{array}{c}-0.0123^{* *} \\
(0.0043)\end{array}$ \\
\hline$N$ & 17 & 17 & 17 & 17 & 17 \\
\hline
\end{tabular}

Notes: See Table 2 notes.

Source: Authors' calculations.

these time points. Panel D shows that the positive effects on being married are largely mirrored by corresponding negative effects on the probability of having never married.

These results suggest that military service induced some men, who otherwise may never have married, to marry for the first time when aged in their 50s. Some caution should be taken with this interpretation, however, given that the point estimates for "never married" in Panel D do not change markedly over the 1966-1986 period. Indeed, the corresponding point estimates for "divorced or permanently separated" in Panel B change slightly more over this period. This suggests that remarriage could also partly explain the positive marriage effect. Regardless, one potential mechanism for the increasing positive effect on being married is veterans' higher pension wealth, which may be advantageous in the marriage market. This is due to earlier eligibility for a retirement pension for the veteran (at age 60 , compared to 65 for non-veterans) and for his wife (55 compared to 60), as well as disability compensation payments for many veterans.

In any case, the results do not support the suggestion that WWII service led to family disruption and dissolution, at least later in life (Damousi 
2001). Similar results were found by other quasi-experimental studies for Australian veterans of the Vietnam War (Siminski and Ville 2012), and for U.S. veterans of WWII (Larsen et al. 2015) and Vietnam (Conley and Heerwig 2013).

\section{CONCLUSION}

Our article is the first econometric study of Australian WWII service, with existing literature largely confined to the qualitative assessments of historians. Unlike most other major combatants, Australia and the United States were outside the main theatres of war and therefore service impact has been one of particular interest. Subsequent wars fought on foreign soil by both nations - Korea, Vietnam, Iraq, and Afghanistan - indicate the ongoing policy significance of the effects of service and the suitability of subsequent repatriation policies such as the GI Bill.

Although the United States entered the war two years later than Australia, the conditions and length of individual service were similar between the two nations, as were the repatriation policies. However, the minimal Australian service in the Korean War enhances the validity of our between-cohort IV approach.

Using data from five subsequent censuses, 1966-1986, we studied the effects of service on a range of socio-economic outcomes, drawing comparisons with American results and the existing Australian historical literature. Our conclusions challenge some of the conventional narratives of Australian historians, succinctly, that war disrupted family life, caused veterans to struggle for work, and who were attracted into higher education by repatriation benefits. In our results, Australian servicemen were minimally disadvantaged in the labor market, were more likely to own a home, somewhat more likely to be married, and more likely to obtain a post-school qualification.

There are some similarities with U.S. results, particularly for housing and marriage, but an important difference is that unlike the U.S. experience, Australia's veterans' education benefits do not seem to have increased the rate of university qualifications. University education was rare at this time in Australia, and perhaps not seen by most veterans as a realistic option. Also, in contrast to the GI Bill, the CRTS was terminated from 1950 and the subsequent expansion of public funding for higher education was not tied to military service.

Perhaps our most intriguing findings are for housing outcomes. Generous housing benefits, which in contrast to the CRTS, continue to be offered to the present, seem to have increased home ownership 
somewhat. However, they had a much larger negative effect on the probability of outright home-ownership (without a mortgage), at least from the 1970s possibly because of the reduced incentive to repay the low-interest loans.

\section{REFERENCES}

Acemoglu, Daron, Tarek Hassan, and James A. Robinson. "Social Structure and Development: A Legacy of the Holocaust in Russia." Quarterly Journal of Economics 126, no. 2 (2011): 895-946.

Akbulut-Yuksel, Mevlude. "Children of War: The Long-Run Effects of Large-Scale Physical Destruction and Warfare on Children." Journal of Human Resources 49, no. 3 (2014): 634-62.

Anderson, D., and E. Eaton. "Part 1: Post-war Reconstruction and Expansion 19401965." Higher Education Research and Development 1, no. 1 (1982): 8-93.

Angrist, Joshua D., and Alan B. Krueger. "Why Do World War II Veterans Earn More Than Nonveterans?" Journal of Labor Economics 12, no. 1 (1994): 74-97.

Angrist, Joshua D., and Jörn-Steffen Pischke. Mostly Harmless Econometrics. Princeton, NJ: Princeton University Press, 2008.

Australian Bureau of Statistics. Year Book Australia, 1938: ABS Cat. No. 1301.1. Canberra, Australia: ABS, 1938.

Australian Bureau of Statistics. Australian Historical Population Statistics, 2014: ABS Cat. No. 3105.0.65.001. Canberra, Australia: ABS, 2014.

Australian Housing Corporation. Defence Service Homes Scheme: Its Nature, History and Operations. Canberra, Australia: Australian Government Publishing Service, 1976.

Beaumont, Joan, ed. Australia's War 1939-45. Sydney, Australia: Allen and Unwin, 1996.

- Australian Defence: Sources and Statistics. South Melbourne, Australia: Oxford University Press, 2001.

Bedard, Kelly, and Olivier Deschênes. "The Long-Term Impact of Military Service on Health: Evidence from World War II and Korean War Veterans." American Economic Review 96, no. 1 (2006): 176-94.

Booth, Alison L., and Hiau J. Kee. "A Long-Run View of the University Gender Gap in Australia." Australian Economic History Review 51, no. 3 (2011): 254-76.

Bound, John, and Sarah E. Turner. "Going to War and Going to College: Did World War II and the G.I. Bill Increase Educational Attainment for Returning Veterans?" Journal of Labor Economics 20, no. 4 (2002): 784-815.

"The Commonwealth-State Housing Agreement." Available online at http://www.aph. gov.au/About_Parliament/Parliamentary_Departments/Parliamentary_Library/ Publications_Archive/archive/StateHouseA_tgree. Accessed 14 December 2015.

Chambers, John W. III, ed. The Oxford Companion to American Military History. New York: Oxford University Press, 1999.

Conley, Dalton, and Jennifer A. Heerwig. "The Causal Effects of Vietnam-Era Military Service on Post-War Family Dynamics.” Social Science Research 42, no. 2 (2013): 299-310. 


\section{The Effects of World War II Military Service}

Costa, Dora. L., and Matthew E. Kahn. "Cowards and Heroes: Group Loyalty in the American Civil War." Quarterly Journal of Economics 118, no. 2 (2003): 51948.

Damousi, Joy. Living with the Aftermath. Trauma, Nostalgia and Grief in Post-War Australia. Cambridge, UK: Cambridge University Press, 2001.

Davidson, Russell, and James G. MacKinnon. Estimation and Inference in Econometrics. New York: Oxford University Press, 1993.

Dennis, Peter, Jeffrey Grey, Ewan Morris, et al. The Oxford Companion to Australian Military History, $2^{\text {nd }}$ ed. South Melbourne, Australia: Oxford University Press, 2008.

Department of Veterans' Affairs (DVA). The Report of the Review of Veteran's Entitlements. Chapter 5: Types of Repatriation Benefits. Canberra, Australia: DVA, 2003.

Elder, Glen H., and Elizabeth C. Clipp. "Wartime Losses and Social Bonding: Influences Across 40 Years in Men's Lives." Psychiatry 51, no. 2 (1988): 177-98.

Fetter, Daniel K. "How Do Mortgage Subsidies Affect Home Ownership? Evidence from the Mid-Century GI Bills." American Economic Journal: Economic Policy 5, no. 2 (2013): 111-47.

Fontana, Alan, and Robert Rosenheck. "Traumatic War Stressors and Psychiatric Symptoms Among World War II, Korean, and Vietnam War Veterans." Psychol. Aging 9, no. 1 (1994): 27-33.

Garton, Stephen. The Cost of War: Australians Return. South Melbourne, Australia: Oxford University Press, 1996.

Goldin, Claudia D., and Lawrence Katz. The Race Between Education and Technology. Cambridge, MA: Harvard University Press, 2009.

Goralski, Robert. World War II Almanac: 1931-1945. London, UK: Hamish Hamilton, 1981.

Grey, Jeffrey. A Military History of Australia. Port Melbourne, Australia: Cambridge University Press, 1990.

Groenewegen, Peter D. Educating for Business, Public Service and the Social Sciences: A History of the Faculty of Economics at the University of Sydney 1920-1999. Sydney, Australia: Sydney University Press, 2009.

Gullett, Henry. Not as a Duty Only: An Infantryman's War. Carlton Victoria, Australia: Melbourne University Press, 1984.

Harrison, Mark, ed. The Economics of World War II: Six Great Powers in International Comparison. Cambridge, UK: Cambridge University Press, 1998.

Hatton, Timothy, and Glenn Withers. "The Labour Market." In The Cambridge Economic History of Australia, edited by Simon Ville and Glenn Withers, 351-72. Port Melbourne, Australia: Cambridge University Press, 2015.

Hill, Malcolm R. "Housing Finance Institutions." In The Australian Capital Market, edited by Ronald R. Hirst and Robert H. Wallace. Melbourne, Australia: Cheshire, 1974.

Ichino, Andrea, and Rudolf Winter-Ebmer. "The Long-Run Educational Cost of World War II." Journal of Labor Economics 22, no. 1 (2004): 57-87.

Imbens, Guido, and Wilbert van der Klaauw. "Evaluating the Cost of Conscription in the Netherlands." Journal of Business and Economic Statistics 13, no. 2 (1995): 207-15. 
Ingold, Bernard P. “The Department of Veterans' Affairs Home Loan Guaranty Program: Friend or Foe." Military Law Review 132, no. 1 (1991): 231-64.

Johnston, Mark. At the Front Line: Experiences of Australian Soldiers in World War II. Oakleigh Melbourne: Oxford University Press, 1996.

Keehn, Robert J. "Follow-Up Studies of World War II and Korean Conflict Prisoners III. Mortality to January 1, 1976." American Journal of Epidemiology 3, no. 2 (1980): 194-211.

Kesternich, Iris, Bettina Siflinger, James P. Smith, et al. "The Effects of World War II on Economic and Health Outcomes Across Europe." Review of Economics \& Statistics 96, no. 1 (2014): 103-18.

Larsen, Matthew, T.J. McCarthy, Jeremy G. Moulton, et al. "War and Marriage: Assortative Mating and the World War II GI Bill." Demography 52 (2015):1431-61.

Lemieux, Thomas, and David Card. "Education, Earnings, and the "Canadian G.I. Bill'.” Canadian Journal of Economics 34, no. 2 (2001): 313-44.

Lloyd, Clement J., and Jacqueline Rees. The Last Shilling: A History of Repatriation in Australia. Carlton Victoria, Australia: Melbourne University Press, 1994.

Long, Gavin M. The Final Campaigns. Australia in the War of 1939-1945. Series 1 (Army) VII. Canberra, Australia: Australian War Memorial, 1963.

- The Six Years War: A Concise History of Australia in the 1939-1945 War. Canberra, Australia: Australian War Memorial and the Australian Government Publishing Service, 1973.

Mackinnon, Alison, and Helen Proctor. "Education." In The Cambridge History of Australia: Volume 2: The Commonwealth of Australia, edited by Alison Bashford and Stuart Macintyre, 429-51. New York: Cambridge University Press, 2013.

Marwick, Arthur. War and Social Change in the Twentieth Century. London, UK: Macmillan Press, 1974.

Pavalko, Eliza K., and Glen H. Elder. "World War Two and Divorce: A Life-Course Perspective." American Journal of Sociology 95, no. 5 (1990): 1213-34.

Phillips, Janet, Michael Klapdor, and Joanne Simon-Davies. Migration to Australia Since Federation: A Guide to the Statistics. Canberra, Australia: Department of Parliamentary Services, 2010.

Robertson, John. Australia at War: 1939-1945. Melbourne, Australia: Heinemann, 1981.

Sampson, Robert J., and John H. Laub. "Socioeconomic Achievement in the Life Course of Disadvantaged Men: Military Service as a Turning Point, Circa 1940-1965." American Sociological Review 61, no. 3 (1996): 347-67.

Siminski, Peter, and Simon P. Ville. "I Was Only Nineteen, 45 Years Ago: What Can We Learn from Australia's Conscription Lotteries?” Economic Record 88, no. 282 (2012): 351-71.

Siminski, Peter, Simon Ville, and Alex Cousley. “The Effects of World War II Military Service: Evidence from Australia." Ann Arbor, MI: Inter-university Consortium for Political and Social Research [distributor], 2017. Available at http://doi. org/10.3886/E100759V1. Persistent URL: http://doi.org/10.3886/E100759V1.

Stanley, Marcus. "College Education and the Midcentury GI Bills." Quarterly Journal of Economics 118, no. 2 (2003): 671-708.

Sutker, Patricia B., and Albert N. Allain. "Assessment of PTSD and Other Mental Disorders in World War II and Korean Conflict POW Survivors and Combat Veterans." Psychological Assessment 8, no. 1 (1996): 18-25. 
Teachman, Jay, and Lucky M. Tedrow. "Wages, Earnings, and Occupational Status: Did World War II Veterans Receive a Premium?" Social Science Research 33, no. 4 (2004): 581-605.

Turner, Sarah, and John Bound. "Closing the Gap or Widening the Divide: The Effects of the G.I. Bill and World War II on the Educational Outcomes of Black Americans." Journal of Economic History 63, no. 1 (2003): 145-77.

Ville, Simon P., and Peter Siminski. "A Fair and Equitable Method of Recruitment? Conscription by Ballot into the Australian Army During the Vietnam War." Australian Economic History Review 51, no. 3 (2011): 277-96.

World War Two Nominal Roll. About this Nominal Roll. Accessed 4 April 2014. Available online at http://www.ww2roll.gov.au/About.aspx. Commonwealth of Australia, 2002. 